\title{
Towards shared unemployment insurance in the euro area
}

\author{
László Andor ${ }^{1,2}$
}

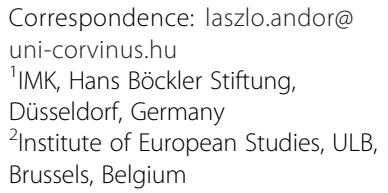

Correspondence: laszlo.andor@ uni-corvinus.hu

${ }^{1}$ IMK, Hans Böckler Stiftung,

Düsseldorf, Germany

${ }^{2}$ Institute of European Studies, ULB, Brussels, Belgium

\begin{abstract}
The divergences developed within the euro area represent the main threat to the existence of the single currency and to the stability of the EU as a whole. Without proper automatic stabilisers, a monetary union can only deliver suboptimal results and may not even be sustainable. In the recent years, common unemployment insurance has been examined as one of the possible ways to improve the functioning of the Economic and Monetary Union (EMU) through automatic stabilisation. Among various options, a partial pooling of unemployment benefit schemes stands out as the model with continuous impact and direct connection with the citizens, while the political process may favour less permanent features and more conditionality. There is a strong case for connecting the EMU reform with the EU social agenda and appreciating risk-sharing in Europe from a political as well as economic point of view.

Jel codes: $\mathrm{E} 24, \mathrm{E} 63, \mathrm{~F} 45, \mathrm{H} 12, \mathrm{H} 53, \mathrm{~J} 65$
\end{abstract}

\section{Introduction}

Since 2012, when the reform of the EMU began, the possibility of and need for unemployment insurance within the Eurozone has been frequently discussed. It has remained a topical issue among economic analysts and policy experts in the face of political headwinds, since most macroeconomists agree today that the incomplete nature of the EMU, and the absence of a counter-cyclical fiscal capacity in particular, makes the single currency unsustainable in its current form. However, there can still be a debate about what should be the next step.

This paper is not suggesting that establishing unemployment insurance at the EMU level would be the only necessary step to make the single currency sustainable, or that it would be a remedy for all ills in the Eurozone. Focusing on divergence, it explores the economic and social problems associated with the absence of an EMU fiscal capacity, and the existing options in the area of automatic stabilisers. Following an overview of key technical questions of how to build unemployment insurance in the context of the Eurozone, it highlights the multifaceted nature of this policy. It is a possible element of economic and monetary reform, while it forms part of the social dimension as well. When political capital is limited, the availability of an instrument that could make a positive impact on both economic and social sides of the crisis should be appreciated by decision makers. 


\section{Divergences as a key problem}

The Five Presidents' Report (FPR) in June 2015 diagnosed the European Economic and Monetary Union (EMU) with severe divergences, outlining the key arguments for revamping the EU's economic and monetary architecture. Rebalancing the EMU is a key issue. Various models of rule-based, though limited, mechanism of risk-sharing have already been explored to strengthen people's and markets' confidence in the common currency.

The EMU was established with an unprecedented divorce between the main monetary and fiscal authorities (Goodhart 1988), with the idea of progressively moving towards full economic integration. The incompleteness of the EMU, however, was fatally exposed once the financial crisis hit and has often been pointed out as a key determinant of the long recession (Enderlein et al. 2015; Obstfeld 2013; O'Rourke and Taylor 2013; Spolaore 2013).

The removal of the exchange rate risk fostered capital flows (Lane 2013), acting as a system of transfers intermediated by financial markets (Hale and Obstfeld 2014), instead through a common fiscal capacity (Pasimeni 2014). The relevance of a common fiscal capacity in monetary unions (Kenen 1969) and the specific case of the EMU were widely discussed in literature before the adoption of the euro (Mundell 1973; Eichengreen 1991; Sala-i-Martin and Sachs 1991; Feldstein 1992; Bayoumi and Masson 1995).

At the same time, the lack of exchange rate excluded an important adjustment mechanism, without creating a new one. The imbalances accumulated during the pre-crisis period were paving the way for an asymmetric effect of the shock caused by the financial crisis (Regan 2015). The post-Lehman sudden stop in financial flows and the Great Recession affected countries differently: deficit countries were forced to adjust and got greater harm; surplus countries could choose not to adjust, and so they did.

In the absence of self-correction mechanisms, the first decade of the EMU made some countries more vulnerable through accumulating financial imbalances in the private sector. Some noticed that the whole EMU existence has been characterised by symmetric divergences in the current account balances and unemployment rates of the participating countries (Pasimeni 2015): up to the crisis, unemployment rates were converging while the external balances were diverging (Fig. 1).

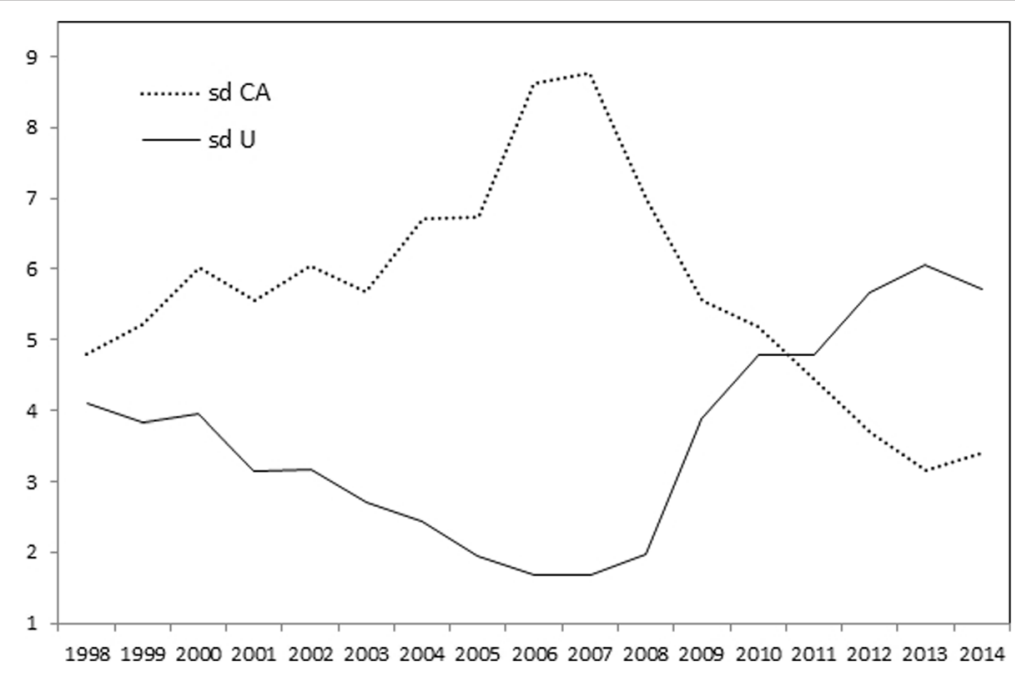

Fig. 1 Divergences in current accounts and unemployment rates. Source: Pasimeni (2015) 
Some saw in this dynamic a positive sign of integration (Blanchard and Giavazzi 2002). Once the sudden stop occurred and the external imbalances had to be adjusted, however, unemployment rates started diverging dramatically.

The divergences developed within the currency area represent the main threat to the existence of the single currency (Draghi 2015), and to the stability of the EU as a whole, hence the need to reform the EMU architecture and, in particular, to strengthen its real economic performance and its social dimension.

Without significant improvements in real economic and social outcomes for all citizens, rising dissatisfaction will continue to turn against the EU, and European nations will gradually turn against each other. Nicholas Kaldor's fear (1971) that monetary union imposed under inappropriate conditions could backfire and generate political pressures against integration is being proved right.

\section{The Maastricht model}

The Maastricht model of the EMU did not foresee any adjustment mechanism to prevent or correct imbalances and divergences. It did not take full account of unemployment as a key indicator and "an all-out threat to monetary stability" (Dornbusch 1996) but focused on fiscal discipline, neglecting the financial one (Dornbusch 1997). Thus, it has serious limitations to handle economic cycles and asymmetric shocks; as a result, dangerous divergences have developed in the years of the crisis (Andor 2013a). Europe today is more imbalanced than before, in terms of the growth potential of its various parts. The core and periphery of the Eurozone have become more divided, and the employment and social situation perfectly exemplify this polarisation.

The accumulation of imbalances in the external positions of Member States needed permanent transfers to be sustained. These transfers have been operated through the financial markets but suddenly stopped after the Lehman shock (Constâncio 2014). At that point, these imbalances could not be sustained anymore, and the pressure to correct them has naturally been stronger on deficit countries than on surplus ones: the "secular international problem that throws the main burden of adjustment on the country which is in the debtor position on the international balance of payments", as (Keynes 1980) clearly explained.

Without the exchange rate mechanism, and in the absence of a lender of last resort, a central budget able to provide fiscal stimulus, or at least coordinated policies aiming to uphold aggregate demand across Europe through a revaluation in "surplus" countries, those economies experiencing balance-of-payments problems inevitably have to undertake an internal devaluation to regain cost competitiveness. This has clearly adverse effects on employment and the social situation, because it leads to unnecessary economic losses and has a devastating social impact (Feldstein 1992; Andor 2013b).

Moreover, if several countries simultaneously try to pursue this strategy, the whole area is trapped into a deflationary spiral (Arestis and Sawyer 2012). The contemporary strategies of fiscal consolidation have weakened the effectiveness of automatic fiscal stabilisers at the national level, i.e. the ability of a state to immediately act in a countercyclical way as tax revenues drop and social expenditure increases.

As a consequence of this flawed mechanism, between end-2011 and end-2013, all components of domestic demand in the Eurozone shrank, and for seven consecutive quarters, the only positive contribution to GDP growth came from net exports. No 
wonder, then, that the period was characterised by a longer recession than in the postLehman worldwide financial crisis.

This vicious circle suggests that there is a need for a mechanism to help maintaining aggregate demand in countries having to adjust at the time of economic downturns and to directly support the innocent victims of this adjustment, who are the unemployed. In the absence of such countercyclical mechanism, divergence becomes manifest between the recovery capacities of the Eurozone core and periphery and even more between their powers to tackle high unemployment (Andor 2015).

\section{EMU reconstruction has begun}

Recent developments signal that the reform of the EMU has begun. This is a process that has been framed by the 2012 report of four presidents (Van Rompuy 2012) and already delivered an initial although incomplete version of the banking union. The creation of a fiscal capacity at the level of the EMU was clearly advocated in the Blueprint ${ }^{1}$ for a deep and genuine EMU, which the European Commission put forward in November 2012 (European Commission 2012).

As a first step in EMU reform, a banking union is in the process of being implemented. However, the Common Deposit Insurance Scheme is not in place and there is no agreement over its establishment. Moreover, without a robust fiscal backstop, the whole architecture is adding more financial instability rather than the opposite. The absence of these two pillars does not allow breaking the sovereign-bank nexus, as recently noted (Padoan 2015). This minimalist banking union could not be sufficient to avoid future banking crises (De Grauwe 2013b) and will do little to mitigate the EMU's bias towards internal devaluation as the predominant adjustment mechanism during balance-of-payments crises. Governments may still find themselves forced towards procyclical fiscal consolidation in times of a downturn.

Coordination of fiscal and structural policies within the EU was strengthened through a series of legislative acts ${ }^{2}$ in order to reassure financial markets of the Member States' commitment to the EMU. Many other elements of economic and political union remained lacking though. These new instruments have been proposed to protect one group of innocent victims of financial crises, which are the taxpayers. But they are not the only ones affected. A second group of innocent victims, those who became unemployed, have borne the full burden of the adjustment.

In parallel with the establishment of the banking union, the social dimension of the EMU was looked at, driven by the observation that the welfare state has been substantially weakened. In particular, the effectiveness of the so-called automatic fiscal stabilisers at the national level meant the ability of a state to immediately act in a countercyclical way as tax revenues drop and social expenditure increases.

Unemployment increased over $11 \%$ in the EU and $12 \%$ in the euro area in 2013, but it became twice as high in those countries going through a painful process of internal devaluation. In these countries, poverty has also risen significantly, demand for the services of food banks has grown and many young people lacking opportunities had to emigrate, often to other continents. In the short term, the forced emigration of young and educated people erodes the tax base of their home countries; in the longer run, it also reduces its economic potential through a worrying loss of human capital. 
This social crisis cannot be considered as a matter of subsidiarity. Social policy alone, even if national welfare systems are reformed, cannot handle the social consequences of the Eurozone crisis. Given the constraints which membership in a monetary union implies, it is fundamental to re-create possibilities of macroeconomic adjustment inside the Eurozone whereby aggregate demand and economic growth can be maintained. When the Commission introduced a scoreboard in October 2013 of key employment and social indicators, it demonstrated that overall unemployment and youth unemployment and inactivity, along with income inequality and poverty, all showed significant and dangerous divergence during the crisis, especially inside the euro area (European Commission 2013a).

Why did Europe become so divided in terms of economic and social outcomes? A key factor has been the design of the EMU, with monetary policy being centralised at the European Central Bank, but fiscal and structural policies being predominantly under the responsibility of national governments, without there being any euro area budget in place. This means that instruments that were historically used to limit the social impact of crises were not available any more, while there has been nothing newly introduced to replace them. This also means that the Europe 2020 targets cannot be expected to be achieved, not even with big delay.

Without adequate macroeconomic intervention capacity, only limited temporary results can be achieved. Better governance and a stronger coordination of social policies is possible but insufficient to restore the potential of convergence. The social dimension of the EMU is crucial for the legitimacy of the European project but also-given the deep integration of our policies-for the legitimacy of national policies. However, it cannot be pursued in the same way as the social dimension of the single market. The latter is mainly a matter of legislation, while strengthening the social dimension of the EMU is fundamentally a matter of financial and monetary instruments.

\section{The case for automatic fiscal stabilisers in the EMU}

In a deflationary environment, a protracted period of low or negative growth will cause the decline of both human and fixed capital, which will in turn undermine growth potential. There is evidence that unemployment caused by the cyclical downturn is becoming structural in the euro area (European Commission 2015). Given the very limited chances of overcoming such imbalances through increased labour mobility in the EU (Draghi 2014), a rule-based stabiliser mechanism becomes an appropriate solution.

If short-term shocks and private sector deleveraging cannot be mitigated by autonomous monetary policy, they have to be absorbed by fiscal policy. Structural reforms cannot be the main answer to cyclical developments. Fiscal instruments are needed not to replace but to supplement other adjustment mechanisms, like structural reforms and labour mobility (Enderlein et al. 2013).

An automatic stabiliser at the EMU level would help uphold aggregate demand at the right time (Delpla 2012), and it would prevent short-term crises from unleashing longer-lasting divergence within the monetary union (Chopin \& Fabre 2013). It would provide an answer to the simple question of a disillusioned European voter: "Where is Europe when we need it most?"

At the same time, a fiscal stabiliser would not represent "more Europe" for its own sake and certainly not more intrusion of Brussels into national policy-making. It would 
constitute a mechanism that strengthens the autonomy of each Member State precisely by stabilising the EMU, on the basis of transparent rules.

The involvement of social partners in the governance of the fiscal capacity would provide a concrete meaning for the strengthening of the social dimension and the participatory principle, also addressing concerns about the democratic deficit and technocratic economic governance in Europe.

The main rationale for setting up such a stabilisation function for EMU is that sound fiscal policies at the national level can allow the automatic stabilisers to work more freely; however, these national fiscal stabilisers might not be sufficient to smooth the cycle within individual countries, maintain economic convergence and deliver the optimal fiscal stance for the euro area as a whole (Italianer \& Pisani-Ferry 1994). This was the case during recent years when national budgets, even in countries with a sound underlying fiscal position, were overwhelmed in a very severe crisis, and the lack of national fiscal stabilisation in turn harmed the whole euro area.

Focusing fiscal transfers on mitigation of asymmetrically distributed cyclical shocks means that over the long term, all participating Member States are likely to be both contributors and beneficiaries of the scheme. But even if the balance is not exactly zero after a certain period of time, the capacity of the system to reduce the duration and deepness of economic crises would provide a more stable macroeconomic environment for all, sustain aggregate demand and therefore improve growth perspectives for the whole area.

A variety of models can be designed; however, a few key questions have to be answered. First: should the stabilisation mechanism compensate for income losses (based on the calculation of an income gap), or should it be linked to the rise of unemployment? Secondly, should the scheme function permanently (even if directions of transfers can frequently change), or should transfers be triggered by key indicators reaching a certain threshold (de facto semi-automatic stabilisation)?

\subsection{An unemployment insurance scheme}

The importance of unemployment as a driving indicator should be emphasised. A major advantage of basing an EMU-level shock absorber on short-term unemployment is that this indicator very closely follows developments in the economic cycle. It is easily understandable and it is easily and promptly measurable (as compared, for instance, to the output gap). People know very well that if periods of adjustment result in withdrawing support from the unemployed, the chances of new employment will diminish and the resulting human capital loss will just get greater, causing further damage to the growth potential of a country.

Common unemployment insurance in the EMU can be one of the possible instruments to improve the functioning of the single currency and, at the same time, to address the social divergences produced by the crisis. The idea and the concept of unemployment insurance is not new: in 1975, the European Commission put it forward in the Marjolin Report (European Commission 1975), arguing that such a mechanism for stabilisation and redistribution was needed if the project of a monetary union, proposed in the Werner Report (Werner 1970), was to be realised. The report suggested the option that such a scheme would generate transfers from 
regions with high structural unemployment to regions with low structural unemployment.

In the early 1990s, some already argued that such a scheme was necessary in view of the forthcoming monetary union, simulating its effects (Italianer and Vanheukelen 1993). They proposed a common unemployment benefit scheme, conducting an analysis at country level, and suggested that such a mechanism could be activated by a higher increase of the unemployment rates over the previous year greater than the average increase of the other EU countries, with a replacement rate of $70 \%$.

\subsection{Recent proposals}

After the establishment of the EMU, little attention was devoted to this option, until the euro crisis revealed its need. ${ }^{3}$ The European Commission included reference to unemployment insurance as one form of automatic stabilisers in two key documents: first, in the Blueprint on the deep and genuine EMU and, 10 months later, in the Communication on strengthening the social dimension of the EMU. This also shows that the idea emerged primarily not from the social agenda of the EU but from the need to reform the EMU, in the wake of a Eurozone crisis which produced dire social consequences in large areas of the Eurozone periphery.

The idea of a basic European unemployment benefit scheme has been recently advocated by Sebastian Dullien, and it also has been analysed by the European Commission's DG Empl with the involvement of a number of external experts. A scheme based on the concept of income insurance ${ }^{4}$ as one option has also been explored by the Commission, DG Ecfin.

Dullien (2013) suggested a scheme based on the payroll tax, insuring directly the unemployed across Europe and giving rise to a specific European fund which could run surpluses and deficits, according to the needs, therefore including the possibility of issuing debt.

Dolls et al. (2014) analysed different alternatives for a common unemployment insurance system for the euro area, quantifying the trade-off between stabilisation effects and degree of cross-country transfers. They suggested that contingent benefits could limit the degree of cross-country redistribution but might also reduce the desired insurance effects.

Beblavy and Maselli (2014) proposed a scheme open to all EU countries, not restricted to the euro area, of a maximum duration of 12 months, triggered by an increase of $2 \%$ of the difference between the unemployment rate and the NAWRU, and include a clawback mechanism to prevent permanent transfers.

In 2014, the debate on automatic stabilisers entered the political arena ${ }^{5}$ feeding into the considerations of EMU reconstruction. The French Ministries of Finance and Economy published a brief in June 2014 (Trésor Economics 2014) supporting the establishment of common basic unemployment insurance, to consolidate euro area integration, improve the macroeconomic and financial stabilisation and move towards enhanced coordination of labour market policies. They suggested that such a scheme would need to be implemented in stages.

In November 2014, the Bank of Italy published a paper identifying the broad characteristics that a shock absorber based on unemployment should have in order to be incentive-compatible and politically feasible (Brandolini et al. 2014). The study derives 
empirically the combination of activation thresholds, experience rating, eligibility criteria and benefit generosity to define such a system giving rise to macro-cross-national transfers, activated by a trigger and with partial experience rating. The results of the simulations conducted suggest that even systems that do not redistribute resources between countries can have a considerable stabilisation impact in the medium run.

At the same time, also Deutsche Bank published a research briefing on this topic (Vetter 2014), stressing the problems of "moral hazard" among participating countries, arguing that mechanisms to prevent it would automatically reduce the stabilisation impact of the scheme and that the difficulties to "establish an equilibrium between net contributors and net beneficiaries in the long term" would reduce the chances of political acceptance.

In 2015, the European Commission has launched a major study to examine details and explore possible implications of EMU unemployment insurance.

In October 2015, the Italian Minister of Finance has stressed the need for "a European mechanism to mitigate the cyclical unemployment and its consequences" (Padoan 2015) and specifically proposed an unemployment insurance scheme, which would be feasible within the limits of the current treaties (MEF 2015). Such a scheme would increase convergence in labour market regulation, consolidate medium-term growth and prevent hysteresis effects. The key point of the Italian proposal is its sense of urgency accompanied by the argument that "such an instrument could be established without treaty changes".

\section{How to design a European unemployment insurance scheme}

The European scheme would not completely replace national ones, being an additional, complementary tool (Andor 2014b). The levels of the contribution and of the benefit should represent a relatively low common denominator between the rules of national schemes, to ensure a fairly basic standard of support during short-term unemployment. Each Member State should be free to levy an additional contribution and pay out a higher or longer unemployment benefit on top of this European unemployment insurance.

A possibility for such a European scheme could be to set up a common fund, which collects and transfers resources between Member States, leaving then to them the task of addressing the individuals. In this case, the fund would operate as an insurance contract among Member States and it could be based on some parameter linked to GDP.

Another option is the possibility that the fund directly pays the benefit to the unemployed persons: in this case, part of the social security contributions would be transferred to the fund, which then would directly address the new unemployed, in every country.

The jobseekers would continue to interact with national authorities (public employment services); however, for it to be effective, a minimum degree of harmonisation would be necessary. Citizens would benefit from EU solidarity at times of hardship, and Member States would be required to upgrade their employment services and labour market institutions to the best EU standards.

The issue of convergence in regulation is an important one. If the Member States agreed to pool more financial, budget and economic sovereignty, there should be a clear framework for social coordination and convergence. Otherwise, it would only lead to more fierce competition between countries, lowering of social standards and 
jeopardising of the social model. As Padoan (2015) has recently argued, such a scheme would provide incentives to increase convergence in labour market regulation, enhancing the capacity for labour market adjustments at the euro area aggregate level.

Jara et al. (2015) find on this respect that if the mechanism would only finance elements of the national schemes that are common across countries, so that the risks are somehow mutual, this common element of existing national schemes would be very small, as it would need to conform to the "lowest" common denominator in every relevant dimension. In the case, instead of a larger stabilisation function, some national schemes would need to be reformed to allow for a larger coverage.

The introduction of a common unemployment insurance scheme would therefore require a minimum degree of harmonisation of labour market regulations, but being it only a topup over national ones, it would not require the creation of a single labour law applied to all countries in order to function. This point is important, because it is sometimes assumed that a European scheme would imply such a complete integration. That is not the case.

Based on basic parameters agreed in advance, the functioning of the scheme would be entirely predictable and calculable on the basis of clear rules. The parameters of the scheme could be adjusted in response to actual experience. At the same time, governments, citizens and financial markets would be able to rely on the principle that an EMU country undergoing a cyclical downturn receives a limited fiscal transfer to support the cost of short-term unemployment.

The issue of net benefits and contributions for each country, at any given point in time, should be to some extent secondary. However, it is understandable that national politicians would probably want to make sure that their country is not permanently a net contributor and especially that there are no free-riders in the scheme (Hess 2015). The limited volume and limited duration of transfers should reduce moral hazard concerns.

There are four key issues to highlight when we consider the risk of moral hazard between participating countries. First of all, participation in a monetary union tends to amplify divergences in the balance of payments (Friedman 1953; Kaldor 1971) and these differences are likely to persist (Fleming 1971). Given the natural asymmetric pressure to adjust on deficit and surplus countries (Keynes 1980), a big problem of "moral hazard" arises on surplus countries. Therefore, a correction mechanism is needed.

Second, the stabilisation capacity of such a mechanism is inversely proportional to the degree of transfers operated. Therefore, there is an important trade-off between the prevention of "moral hazard" in the use of the instrument and its effectiveness (Fattibene 2015).

Third, the risk of "lasting transfers" through a common unemployment benefit scheme could be minimised by two mechanisms, which already exist in federal unemployment insurance systems elsewhere in the world, namely experience rating ${ }^{6}$ and clawbacks. ${ }^{7}$

Fourth, studies have proved that even systems that do not redistribute resources between countries can have an important stabilisation impact in the medium run (Brandolini et al. 2014).

\section{Costs and benefits of a European unemployment insurance scheme}

It is important to have a clear view of the potential costs and benefits associated with such a scheme. One of the first simulations of a common unemployment benefit scheme (Italianer and Vanheukelen 1993) suggested that it would amount to $0.5 \%$ of 
GDP and have a stabilisation effect of $20 \%$ across the EU. Dullien (2013) suggested an annual cost of the scheme between 0.3 and $0.6 \%$ of GDP, and the stabilisation effects of the system, calculated as GDP deviation from a potential GDP trend, would increase on average by $11 \%$ for the whole area; however, the net effect in a recession in most countries would be much larger.

Brandolini et al. (2014) estimate that over the decade 2002-2012, such an instrument would have had a stabilisation effect, calculated as the reduction in the coefficient of variation of GDP within the euro area, by $0.03 \%$. Beblavý and Maselli (2014) use a different measure of stabilisation, by looking at the ratio between net payments to the fund and total GDP, instead at the deviation of GDP from its trend. With such a methodology, they find a multiplier effect of 1.5. Dolls et al. (2014) find a stabilisation effect ranging between 23 and $31 \%$ for Greece, Ireland, Italy, Portugal and Spain, during the first years of the present crisis.

All simulations suggest that it would absorb less than $1 \%$ of the countries' GDP. As a matter of reference, the only study which assumes a total coverage of unemployment benefit costs of countries (Pisani-Ferry et al. 2013) calculates that between 2002 and 2010 such a scheme would have represented on average $1.8 \%$ of GDP. However, this study overestimates the size of a scheme, which would instead be only a partial complement, at European level, of national insurance policies. All other analyses suggest figures well below $1 \%$ of GDP, depending on the exact parameters such as duration and level of the benefit or the eligibility conditions. Whittaker and Isaacs (2014) have calculated that such a benefit scheme in the USA amounted to less than $0.3 \%$ of GDP in 2014.

An automatic fiscal stabiliser in the form of basic European unemployment insurance would have a meaningful macroeconomic effect in counteracting a cyclical downturn; it would help to uphold domestic demand and sustain growth in Europe as a whole. This means helping EMU countries to share part of the financial risk associated with cyclical unemployment caused by a drop in aggregate demand and not compensating for structural differences caused by skills mismatches, less efficient labour market institutions and the like. ${ }^{8}$

The fact that the scheme would trigger countercyclical transfers automatically and immediately is a major advantage compared to bailout programmes or bank rescues. These are always surrounded by uncertainty, which pushes up their cost. The basic European unemployment insurance scheme would be relatively cheap precisely because of its automaticity, also compared to discretionary fiscal instruments, where a fiscal transfer would be provided in exchange for structural reforms. The "catalogue" of reforms and corresponding financial support under such discretionary instruments would be very hard to define, and the decision-making process would be rather unpredictable, not to mention the political tensions arising around the approval of discretionary cross-country transfers.

Like a more flexible interpretation of the EMU's fiscal rules, partial pooling of fiscal risks at the EMU level would provide national governments with greater fiscal leeway. However, the big advantage of achieving countercyclical stimulus on the basis of crosscountry transfers rather than more flexible rules for national budgets is precisely in the collective character of the EMU-level scheme.

Consolidation of the monetary union through common fiscal stabilisers would reduce uncertainty about individual countries' solvency both in the short and in the longer 
term. In addition, a basic European unemployment insurance scheme would strengthen the EMU institutionally, politically and in terms of social cohesion.

The predictability, limited volume and limited duration of fiscal transfers would also make a basic European unemployment insurance scheme a much safer option than various scenarios for mutualisation of Eurozone countries' sovereign debt. This feature is particularly important when Member States consider themselves in the role of a contributor rather than a beneficiary.

With its automatic and countercyclical character, a basic European unemployment insurance scheme could boost market confidence in the EMU and thus help to avoid repeating vicious circles of downgrades, austerity and internal devaluation in the Eurozone. It would help to uphold domestic demand and therefore economic growth in Europe as a whole.

While individual stimulus by countries with high debt-to-GDP ratios may run the risk of triggering further financial crises, consolidation of the monetary union through common fiscal stabilisers would reduce uncertainty about individual countries' solvency both in the short and in the longer term. In addition, a basic European unemployment insurance scheme would strengthen the EMU institutionally, politically and in terms of social cohesion.

\section{Alternatives and limitations}

The need for rebalancing within the euro area is often used as a leverage to force country-specific reforms to improve the microeconomic efficiency of the economic structure. Structural reforms can play an important role to enhance potential growth, but they primarily provide a boost to long-term potential, without a short-term capacity to stimulate the economy. In the history of financial crises in emerging economies, they always functioned in combination with currency devaluation.

Labour mobility is another common argument used to explain how the euro area could function better as a currency area. In theory it offers a solution to imbalances, but in reality it can only play a minor role, especially in such a fragmented labour market as the EU (Draghi 2014; Beyer and Smets 2015). The Eurozone crisis has triggered new migration of workforce, but often towards other continents, causing a long-term human capital loss to the EU.

There is virtually no serious assessment of the functioning of the euro area that would see a chance of long life without a fiscal capacity and risk-sharing (Solow 2005; De Grauwe 2013a), ideally in some form of automatic stabilisers that can limit the damage from cyclical downturns.

Once the need for a fiscal tool is identified, a possible alternative could be an investment fund. Such a fund could be similar to the option presented above in the sense of contributions linked to GDP but could probably be also linked to the output gap as a measure of cyclical conditions. The key problem of such an indicator is that the "realtime output gap" is not very reliable. This fund, however, on the expenditure side could finance large-scale public investments to boost the economic potential of the area.

The common unemployment insurance scheme stands out as probably the best option to improve the sustainability of the euro area. It could, however, present some limitations. The main ones relate to the political acceptability in countries where the narrative of the recent crisis has only focused on supposed wrongdoing and misbehaviours of other countries in the pre-crisis period. After years of continuous 
propaganda, how could the narrative change and suddenly explain that helping each other out in terms of sharing a little part of social security is actually beneficial for the whole system?

Another limitation, linked to the previous one, is more technical in nature: while many simulations show that over the medium term there would be no permanent country beneficiaries or contributors, perfect neutrality of the system is not certain. Moreover, the exact definition of the "medium term" cannot be imposed ex ante. These issues may render the acceptance of this proposal politically difficult.

\section{Conclusions and implications: political feasibility of an EMU reform}

Before leaving office, President Jose Manuel Barroso identified the EMU's reform as the most important task for the next period. ${ }^{9}$ And shortly after entering office, in February 2015, President Jean-Claude Juncker submitted an "analytical note ${ }^{10}$ " to the European Council about the deepening of the EMU. Leadership is now required to find solutions that may not sound obvious, but which are necessary to leave behind the quagmire.

The incomplete EMU proved to be-at best-a structure for fair weather, but not for a financial and economic crisis. It represents a competitive disadvantage for Europe vis-a-vis the USA and Japan. The excessive burden of adjustment on deficit countries will continue to erode political support for the single currency, and the eventual breakdown will only be a matter of time.

If the single currency is to be kept, the original Maastricht design has to be replaced with one supported by a stabilisation and recovery capacity and with a much stronger social dimension. For that, we need automatic fiscal stabilisers at the euro area level.

The dogma of "no fiscal transfers" in the EMU should be dropped. In a system of single market, high-income countries have to support low-income countries or regions (Monti 2010). In a system of monetary union, surplus countries have to support deficit countries; otherwise, the different problems of moral hazard, on both sides, will inevitably undermine the union.

With the status quo more and more unsustainable economically and politically, the EU has to choose between monetary de-construction and reconstruction. Either the EMU allows each country to be better off inside than outside it, or it will not be sustainable (Draghi 2014). If the EMU is really meant to be irreversible, we must pay attention to the employment and social outcomes and try to prevent lasting divergences.

There are solutions capable of sorting out the macroeconomic bias against full employment in the EU, even though the political complexity of implementing these solutions should not be underestimated. The EU is in a race against time, if it is to make the single currency sustainable and legitimate (Andor 2014a). Discussion of automatic stabilisers and EMU reform in general should therefore be seen as urgent, even if the necessary political momentum is not there. The ECB should be explicitly empowered to act as a true European institution and consider employment as much among its goals as price stability.

All models of EMU unemployment insurance suggest that in a sufficiently long time period (two to three decades), all countries would be net beneficiaries at least once. It is much better to help each other out in times of crisis than to put the fate of the Union and of its individual members at stake whenever a financial crisis occurs.

Without concrete initiatives towards a better functioning model, de-construction will present itself as the more appealing option towards the end of this decade (Nordvig 2004). 
The consequences would be much more unpredictable than limited fiscal risk-sharing in a basic European unemployment insurance scheme.

The EMU can only fulfil its unifying mission if the costs and the benefits of the EMU are more fairly distributed among the participating states and if the rules of the game help boosting the growth potential of all of them.

If this chance is missed, and divergence and asymmetries are not dealt with, continuing stagnation will turn even greater shares of the electorate against the euro as well as the EU. Reconstruction will be blocked, and the only choice will be between orderly or disorderly de-construction.

\section{Endnotes}

${ }^{1}$ The Blueprint gave evidence that the Commission understood the root causes of the crisis and the necessity of reconstruction, even if it was bound to remain a rather technocratic document, as compared to the more political Thyssen report in the European Parliament, also encompassing the social dimension.

${ }^{2}$ The European Semester, the Six-Pack, the Two-Pack and the Treaty on Stability, Coordination and Governance

${ }^{3}$ The debate has been developed through two Commission documents, two expert conferences, two Council debates and several independent studies-all in between two Presidents' Reports.

${ }^{4}$ European Commission, DG Ecfin: income insurance: a theoretical exercise with empirical application for the euro area, 23 March 2015

${ }^{5}$ Under the Italian presidency, informal EPSCO discussed automatic stabilisers in July 2014 and informal ECOFIN in 2014. The first called for a Green Paper on EMU unemployment insurance.

${ }^{6}$ Experience rating means that the contributor vs. beneficiary profile of each Member State in the scheme is monitored and the contribution or drawdown parameters can be adjusted at the beginning of each period so as to bring the Member State closer to a projected balance with the scheme over the medium term.

${ }^{7}$ Clawbacks, on the other hand, enable to neutralise net transfers ex post, meaning that Member States are allowed to be net beneficiaries for several years, but then their contribution and/or drawdown rates are modified so as to compensate for the net transfers that had occurred.

${ }^{8}$ It is important not to exclude workers in short-term or part-time jobs from contributing and qualifying for the support, with the attached conditionality in terms of job search and training effort.

${ }^{9}$ JMDB: On Europe. Speech at Humboldt University, 8 May 2014

${ }^{10}$ The analytical note was prepared in close cooperation with European Council President Donald Tusk, Eurogroup President Jeroen Dijsselbloem and European Central Bank President Mario Draghi. It does not call for separate institutions, or a budget for the Eurozone, or mention a potential EU treaty change. But it does raise a number of questions which potentially lead to those directions. 


\section{Author's information}

László Andor is a former EU Commissioner for Employment, Social Affairs and Inclusion (2010-2014). Head of Department of Economic Policy (Corvinus University of Budapest).

\section{Acknowledgements}

I would like to thank Lukas Vesely and Paolo Pasimeni for their useful comments on the draft of this paper. Their contribution helped the shaping of the final version, for which the author alone is responsible. I would also like to thank the anonymous referees and the editor for the helpful remarks.

Responsible editor: Martin Kahanec

Received: 19 October 2015 Accepted: 17 March 2016

Published online: 27 May 2016

\section{References}

Andor L (2013a) Speech at the ETUC Conference "celebrating the past, looking to the future", Europeans want and deserve a monetary union with a human face. Madrid, 28 January 2013. http://europa.eu/rapid/press-release_ SPEECH-13-62_en.htm?locale=en

Andor L (2013b) Can we go beyond the Maastricht orthodoxy? In. voxeu.org. 13 December, 2013: http://www.voxeu. org/article/can-we-move-beyond-maastricht-orthodoxy

Andor L (2014a) Speech at the Hertie School of Governance. Berlin, June 2014. http://europa.eu/rapid/press-release_ SPEECH-13-62 en.htm?locale=en

Andor L (2014b) Basic European unemployment insurance - the best way forward in strengthening the EMU's resilience and Europe's recovery. Intereconomics 49, July/August 2014. http://archive.intereconomics.eu/year/2014/ 4/designing-a-european-unemployment-insurance-scheme/

Andor L (2015) Is high unemployment here to stay? In: Europe's World. March 26 2015, Spring 2015. http://europesworld. org/2015/03/26/highunemployment-stay

Arestis P, Sawyer M (eds) (2012) The Euro crisis. Palgrave Macmillan, London, ISBN: 9781137018779. Publication Date: April 2012

Bayoumi T, Masson PR (1995) Fiscal flows in the United States and Canada: lessons for monetary union in Europe. Eur Econ Rev 39(2):253-274

Beblavý M, Maselli I (2014) An unemployment insurance scheme for the euro area: a simulation exercise of two options, CEPS special report n. 98. Brussels., Beblavý M, Gros D, Maselli I (2015) Reinsurance of national unemployment benefit schemes, CEPS WD n. 401. http://europa.eu/rapid/press-release_SPEECH-13-62_en.htm?locale=en

Beyer R, Smets F (2015) Labour market adjustments in Europe and the US: how different?., (March 23, 2015). ECB working paper No.1767

Blanchard O, Giavazzi F (2002) Current account deficits in the euro area: the end of the Feldstein-Horioka puzzle? Brook Pap Econ Act 2002(2):147-209

Brandolini A, Carta F, D'Amuri F (2014) A feasible unemployment-based shock absorber for the euro area", Questioni di Economia e Finanza (Occasional Papers) No. 254. Banca d'Italia, Rome. http://europa.eu/rapid/press-release_ SPEECH-13-62 en.htm?locale=en

Chopin T, Fabre A (2013) L' "Europe sociale", levier d'intégration de la zone euro, 21/10/2013, http://www.robertschuman.eu/fr/questions-d-europe/0292---europe-sociale-levier-d-integration-de-la-zone-euro

Constâncio V (2014) The European crisis and the role of the financial system. J Macroecon 39:250-259

De Grauwe P (2013a) Design failures in the Eurozone: can they be fixed? LSE 'Europe in question' discussion paper series

De Grauwe P (2013b) The new bail-in doctrine: a recipe for banking crises and depression in the Eurozone., CEPS commentary

Delpla J (2012) A Euro-wide conditional unemployment insurance', paper prepared for the Seminar 'EU level economic stabilisers'., (July 2, 2012), draft: June 2012

Dolls M, Fuest C, Neumann D, Peichl A (2014) An unemployment insurance scheme for the euro area? A comparison of different alternatives using micro data. (October 28, 2014), ZEW-Centre for European Economic Research discussion paper, (14-095)

Dornbusch R (1996) Debt and monetary policy: the policy issues (No. w5573). Natl Bur Econ Res 1-32

Dornbusch R (1997) Fiscal aspects of monetary integration. Am Econ Rev 87(2):221-223

Draghi M (2014) Stability and prosperity in monetary union, Speech by the President of the European Central Bank, at the University of Helsinki. 27 November 2014

Dullien S (2013) A European unemployment insurance as a stabilization device — selected issues and a euro-area wide unemployment insurance as an automatic stabilizer: who benefits and who pays?., European commission DG EMPL, Dullien and Fichtner (2013) A common unemployment insurance system for the euro area. DIW economic bulletin 3(1):9-14

Eichengreen B (1991) Is Europe an optimum currency area? (No. w3579). Natl Bur Econ Res 1-28

Enderlein H, Guttenberg L, Spiess J (2013) Making one size fit all: designing a cyclical adjustment insurance fund for the Eurozone, Notre Europe Institute, policy paper, N 61

Enderlein H, Fritz-Vannahme J, Haas J (2015) Repair and prepare: strengthening Europe's economies after the crisis., 30 January, http://www.delorsinstitute.eu/011-20891-Repair-and-prepare-Strengthening-Europe-s-economies-after-the-crisis.html

European Commission (1975) Report of the study group "Economic and Monetary Union 1980" and annex I. (Marjolin Report)

European Commission (2012) A Blueprint for a deep and genuine Economic and Monetary Union: launching a European debate, 28/11/2012

European Commission (2013a) Strengthening the social dimension of the Economic and Monetary Union, 2/10/2013

European Commission (2015) Quarterly report on the euro area. Eur Econ 14:3, October 2015

Fattibene D (2015) Creating a union with a "human face": a European unemployment insurance, http://www.iai.it/en/ pubblicazioni/european-unemployment-insurance\#sthash.kjcl7425.dpuf 
Feldstein M (1992) The case against the euro, The Economist., 1992

Fleming JM (1971) On exchange rate unification. Econ J 81:467-488

Friedman M (1953) "The case for flexible exchange rates", published in Friedman's essays in positive economics. University of Chicago Press, London, pp 157-203

Goodhart C (1988) The two concepts of money: implications for the analysis of optimal currency areas. Eur J Polit Econ 14:407-432

Hale G, Obstfeld M (2014) The Euro and the Geography of International Debt Flows, NBER Working Paper No. 20033

Hess R (2015) The political feasibility of an automatic fiscal stabilizer for the Eurozone (unpublished master's thesis). Hertie School of Governance, Berlin

Italianer A, Pisani-Ferry J (1994) The regional stabilisation properties of fiscal arrangements. In: Mortensen J (ed) Improving economic and social cohesion in the European community

Italianer A, Vanheukelen M (1993) Proposals for community stabilization mechanisms: some historical applications". In: The economics of community public finance, European economy: reports and studies, no. 5. European Commission, Brussels

Jara Tamayo HX, Tumino A, Sutherland H (2015) The redistributive and stabilising effects of an EMU unemployment benefit scheme under different hypothetical unemployment scenarios (No. EM18/15), EUROMOD at the Institute for Social and Economic Research

Juncker JC, Tusk D, Dijsselbloem J, Draghi M, Schulz M (2015) Completing Europe's economic and monetary union. Five Presidents' Report, June

Kaldor N (1971) The dynamic effects of the common market, New Statesman., 12 March 1971

Kenen P (1969) The theory of optimum currency areas: an eclectic view. In: Mundell R, Swoboda A (eds) Monetary problems in the International Economy. University of Chicago Press, London

Keynes JM (1980) Activities 1940-1944, shaping the post-war world: the clearing union, The collected writings of John Maynard Keynes, Royal Economic Society. MacMillan and Cambridge University Press, London, Vol. XXV

Lane PR (2013) Capital flows in the euro area (No. 497), European economy-economic papers., DG Economic and Financial Affairs, European Commission

MEF (2015) European unemployment insurance scheme, Ministero dell'Economia e delle Finanze. October. Rome. http://europa.eu/rapid/press-release_SPEECH-13-62_en.htm?locale=en

Monti M (2010) A new strategy for the single market, Report to the President of the European Commission José Manuel Barroso., May, 10

Mundell R (1973) In: Johnson HG, Swoboda AK (eds) Uncommon arguments for common currencies

Nordvig J (2014) The fall of the euro. Reinventing the Eurozone and the future of global investing. McGraw-Hill, New York Obstfeld M (2013) Finance at center stage: some lessons of the euro crisis, EUROPEAN ECONOMY Economic Papers., p 493

O'Rourke KH, Taylor AM (2013) Cross of Euros. J Econ Perspect 27(3):167-192

Padoan PC (2015) Making progress in Economic and Monetary Union, Speech delivered at University of Luxembourg., October 6

Pasimeni P (2014) An optimum currency crisis. Eur J Comp Econ 11(2). December 2014 http://eaces.liuc.it/ 18242979201402/182429792014110201.pdf

Pasimeni P (2015) The economic rationale of an EMU fiscal capacity, proceedings of the Oesterreichische Nationalbank Workshop "Towards a Genuine Economic and Monetary Union". Vienna, September 2015. http://europa.eu/rapid/ press-release_SPEECH-13-62_en.htm?locale=en

Pisani-Ferry J, Vihriälä E, Wolff G (2013) Options for a Euro-area fiscal capacity, Bruegel Policy Contribution No. 2013/01. Brussels. http://europa.eu/rapid/press-release_SPEECH-13-62_en.htm?locale=en

Regan A (2015) The imbalance of capitalisms in the Eurozone: can the north and south of Europe converge? Comparative European Politics

Sala-i-Martin X, Sachs J (1991) Fiscal federalism and optimum currency areas: evidence for Europe from the United States (No. w3855), NBER

Solow R (2005) Rethinking fiscal policy. Oxf Rev Econ Policy 21(4):509-514

Spolaore E (2013) What is European integration really about? A political guide for economists. J Econ Perspect 27(3):125-144

Trésor Economics (2014) An unemployment insurance scheme for the euro area, N.132., June 2014

Van Rompuy H (2012) Towards a genuine economic and monetary union. European Council, Brussels, p 5

Vetter S (2014) Stabilization, solidarity or redistribution? Deutsche Bank Research Briefing on European Integration. Frankfurt am Main, November 2014

Werner P (1970) Report to the council and the commission on the realisation by stages of Economic and Monetary Union in the community - "Werner report" - [8 October 1970], Bulletin of the European Communities, Supplement $11 / 1970$

Whittaker JM, Isaacs KP (2014) Unemployment insurance: programs and benefits. Congressional Research Service, Washington, DC 